\title{
THE IMPACT OF CLINICAL AND GENETIC SCREENINGS ON THE MANAGEMENT OF THE MULTIPLE ENDOCRINE NEOPLASIA TYPE 1
}

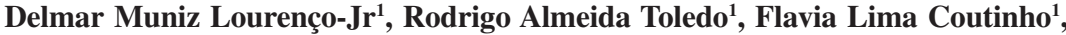 \\ Leontina Conceição Margarido², Sheila Aparecida Coelho Siqueira ${ }^{3}$, Marcelo \\ Augusto Cortina Gonçalves dos Santos ${ }^{1}$, Fabio Luiz de Menezes Montenegro ${ }^{4}$, \\ Marcel Cerqueira Cesar Machado ${ }^{5}$, Sergio Pereira Almeida Toledo ${ }^{1}$
}

Lourenco Jr DM, Toledo RA, Coutinho FL, Margarido LC, Siqueira SAC, Cortina MA, Montenegro FL, Machado MC, Toledo SP. The impact of clinical and genetic screenings on the management of the multiple endocrine neoplasia type 1. CLINICS. 2007;62(4):465-76.

PURPOSE: To perform clinical and genetic screening for multiple endocrine neoplasia type 1 (MEN1) in patients at the Academic Hospital of the University of São Paulo School of Medicine, and to analyze its impact on clinical management of patients with MEN1.

METHODS: The clinical diagnosis of MEN1 was made in accordance with the Consensus on multiple endocrine neoplasias. Mutation analysis of the entire MEN1 tumor suppressor gene and genetic screening of at-risk family members were performed by direct sequencing. To analyze the implementation of genetic diagnosis, the studied patients were separated into 3 groups: MEN1 index cases (group I), clinically diagnosed MEN1 cases (group II), and genetically diagnosed MEN1 cases (group III).

RESULTS: In total, 154 individuals were clinically and genetically studied. We identified 12 different MEN1 mutations. Fifty-two MEN1 cases were identified: 13 in group I, 28 in group II, and 11 in group III. The mean age in group III (27.0 years) was significantly lower than in groups I (39.5 years) and II (42.4 years; $P=0.03$ and $P=0.01$, respectively). Patients in groups I and II mostly presented 2 or 3 MEN1-related tumors, while $81.8 \%$ of those in group III presented 1 or no MEN1-related tumor. Additionally, in group III, $45.4 \%$ of cases were asymptomatic, and no metastasis or death was verified. Surveillance for MEN1 mutations allowed the exclusion of 102 noncarriers, including a case of MEN1 phenocopy.

CONCLUSION: Our data supports the benefits of clinical and genetic screening for multiple endocrine neoplasia type 1 in the management of this syndrome.

KEYWORDS: Multiple endocrine neoplasia. MEN1. MEN1 gene. Screening. Genetic diagnosis.

\section{INTRODUCTION}

\section{Clinical Aspects of the MEN1 syndrome}

Multiple endocrine neoplasia type 1 (MEN1; OMIM

${ }^{1}$ Unidade de Endocrinologia Genética, LIM-25, Endocrinologia ${ }^{2}$ Departamento de Dermatologia

${ }^{3}$ Departamento de Divisão de Anatomia Patológica

${ }^{4}$ Departamento de Cirurgia de Cabeça e Pescoço e

5 Departamento de Gastroenterologia Cirúrgica

Hospital das Clínicas da Faculdade de Medicina da Universidade de São

Paulo - São Paulo/SP, Brasil.

E-mail: toldo@usp.br

Received for publication on July 05,2007

Accepted for publication on July 07, 2007
131100) is an autosomal dominant inherited tumor syndrome mainly characterized by parathyroid, endocrine pancreas, and pituitary tumors. ${ }^{1,2}$ According to the MEN Consensus (2001), the diagnosis of this condition is based on the concomitant occurrence in a patient of at least 2 of these 3 major MEN1-related tumors.

\section{Hyperparathyroidism in MEN1}

Primary hyperparathyroidism (HPT) is the most common clinical feature of MEN1, and it occurs in $73 \%$ to $100 \%$ of cases (Table 1). HPT is usually (80\%) the first clinical manifestation of MEN1. ${ }^{3}$ Primary hyperparathy- 
roidism due to MEN1 (HPT/MEN1) differs from sporadic primary HPT (sHPT) in several aspects, as it presents, a) multiglandular parathyroid hyperplasia or adenoma; b) ageonset 2 decades earlier than sHPT (20 vs 40 years of age); c) sex ratio of $1: 1$ in contrast to the $1: 3$ for $\mathrm{SHPT}$; and d) higher recurrence rates of HPT after parathyroidectomy.,5 Although HPT/MEN1 tends to be less aggressive than sHPT, usually presenting parathyroid hormone (PTH) ranging from 2 to 3 times over the upper normal limits and moderately high calcium levels, 6 "moans, groans, and stones" and renal insufficiency may occur in advanced stages of this disease. In late diagnosed cases, renal dialysis and kidney transplantation may be necessary. ${ }^{5}$

Table 1 - Prevalence (\%) of clinical features in MEN1 disease*

\begin{tabular}{lc}
\hline Endocrine Tumors & \\
\hline Parathyroid adenoma (73-100) & Anterior pituitary tumor (20-40) \\
Prolactinoma (62-76) & NS (14-24) \\
$\begin{array}{ll}\text { Enteropancreatic tumor (30-80) } \\
\text { Gastrinoma ** (30-75) }\end{array}$ & Co-secreting (10) \\
Insulinoma (10-30) & GH-secreting (9) \\
& ACTH-secreting (4) \\
Carcinoids ** (> 10) & TSH-secreting ( rare ) \\
Nonendocrine Tumors & Adrenal cortex NS (12-40) \\
Facial angiofibroma (40-80) & \\
*References 1,3,11,14,18-22 & \\
$* *$ tumor with malignant potential (>25\%); NS, nonsecreting. \\
MEN1 = multiple endocrine neoplasia type 1
\end{tabular}

Surgical management for HPT/MEN1 includes subtotal or total parathyroidectomy followed by an autograph to the forearm, clearly differing from the adenomectomy recommended for sHPT. Furthermore, in MEN1 cases, preventive thymectomy is recommended in association with parathyroidectomy to prevent thymic carcinoids. ${ }^{1,7-10}$ These facts underline the importance of performing the diagnosis of MEN1 for better management of HPT in these patients. ${ }^{7-10}$

The penetrance of HPT in MEN1 in several series has been reported as high as $95 \%$ at 50 years of age, so it has been considered the main clinical feature for the diagnosis of MEN1. Thus, screening for other MEN1-related diseases was initially considered less necessary for recognition of MEN1. Screening for HPT in MEN1 was usually performed only until 50 years of age. However, recent series have shown lower prevalences (50\%-70\%) of HPT as the first clinical characteristic in MEN1 and lower HPT penetrance $(70 \%)$ than previously reported. These findings indicated that HPT surveillance should be performed for longer periods. ${ }^{11,12}$

\section{Endopancreatic tumors in MEN1}

Pancreatic/duodenal endocrine tumors (PETs) occur in up to $30 \%$ to $80 \%$ of patients with MEN1.3,13,14 Gastrinoma in MEN1 is the most prevalent functioning PET, seen in $30 \%$ to $75 \%$ of MEN1 cases ${ }^{5}$. The gastrinomas in MEN1 mostly occur in the duodenum (up to 90\%) and is frequently multifocal, in contrast to unifocal sporadic gastrinomas. ${ }^{5}$ Furthermore, up to $25 \%$ of all gastrinomas are related to MEN1.1,15 Surgical procedures in gastrinoma associated with MEN1 are usually more extensive than those applied to its sporadic counterpart. Enucleation of multiple nodules of the duodenum associated with subtotal (80\%-85\%) pancreatectomy is recommended for patients with MEN1, whereas enucleation of the unique small tumor of the duodenum or pancreas and duodenectomy or partial pancreatectomy for bigger tumors are usually performed for sporadic gastrinomas. ${ }^{16,17}$ Thus, the presurgical MEN1 diagnosis offers the surgeon important information for a better approach regarding PETs in MEN1 cases.

A similar statement was also applied to insulinoma associated with MEN1, which is the second most prevalent functioning PET in MEN1 (10\%-30\%). For patients with insulinoma due to MEN1, subtotal pancreatectomy combined with enucleation of possible nodules of the head of pancreas is the recommended surgical approach . ${ }^{1,5}$ Enucleation of the unique nodule of the pancreas or partial pancreatectomy are the most common surgical approaches to sporadic insulinomas.

\section{Pituitary tumors in MEN1}

Pituitary adenomas have been documented in up to $40 \%$ of MEN1 cases reported in extended series. ${ }^{18-20}$ However, lower prevalences (18\%-21\%) have been also documented by others. ${ }^{21,22}$ In $17 \%$ of MEN1 cases, a pituitary adenoma may be the initial lesion. ${ }^{18}$ Interestingly, age at the diagnosis of pituitary tumors is similar ( 37 yrs) for MEN1, familial isolated pituitary adenomas, and sporadic pituitary tumors. ${ }^{18,23}$ Pituitary adenomas in MEN1 are usually more aggressive and larger than in its sporadic counterpart. Thus, up to $85 \%$ of pituitary tumors associated with MEN1 are macroadenomas ( $32 \%$ invasive), in contrast to $42 \%$ in nonMEN1 cases. ${ }^{18}$

Prolactinoma is the most frequent pituitary disease in MEN1; $62 \%$ to $76 \%$ of patients with MEN1 having pituitary disease present with prolactinoma, although nonsecreting pituitary adenomas are also frequent $(14 \%-24 \%) .{ }^{18,21} \mathrm{Co}$-secreting, GH-, and ACTH-secreting pituitary tumors are less frequent $\left(10 \%, 9 \%\right.$, and $4 \%$, respectively), ${ }^{18}$ whereas $\mathrm{FSH}$ and TSH-secreting tumors are both very rare in MEN1. ${ }^{24}$ 
In addition to the major features of MEN1 mentioned above, up to 20 other endocrine and nonendocrine tumors have been described in association with MEN1 (Table 1). ${ }^{13}$ Due to its extended and widely variable phenotype, MEN1 is presently considered a complex, multisystemic disorder, and its clinical diagnosis may turn to be a difficult task. ${ }^{13}$

Thymic carcinoid tumors and gastrinoma are the major causes of death in MEN1 patients. ${ }^{25,26}$ More than $90 \%$ of MEN1-associated thymic carcinoids are malignant:; ${ }^{25-27}$ however, these tumors are relatively rare. On the other hand, although gastrinomas are usually less malignant $(60 \%)$ than thymic carcinoids, ${ }^{28}$ they can be detected in up to $75 \%$ of MEN1 cases depending on the series (Table 1). Malignancies are responsible for significant lowering ages of death verified for MEN1 (55.4 years for men and 46.8 years for women), as compared to life expectation in the general population ( $>70$ years). ${ }^{29}$

No preventive surgical approach has been shown to significantly improve the outcome of MEN1. ${ }^{1}$ However, it is accepted that the earlier the identification of MEN1 neoplasias, the better the clinical management of this disease. ${ }^{30,31}$ As recommended by the MEN Consensus, the suggested approach for patients with MEN1 is based on periodical surveillance of MEN1-related neoplasias that should begin as early as 5 to 20 years of age. ${ }^{1}$ Surveillance for MEN1 neoplasia is a time-consuming, laborious, expensive, and lifelong procedure that includes clinical, biochemical, and imaging investigations. However, it has been proven to be efficient in the identification of MEN1 tumors and in the reduction of morbidity $^{30}$ and mortality of patients with MEN1..$^{25,26,31}$

Therefore, the establishment of a structured and longterm follow-up program focused on screening for MEN1 would be a worthwhile effort. ${ }^{29}$

\section{Genetic Aspects of MEN1}

Familial MEN1 is an autosomal dominantly inherited disease presenting almost complete penetrance. ${ }^{13}$ The gene responsible for MEN1 (MENI) was identified at 11q13 by two different research groups, one from $\mathrm{NIH}^{32}$ and another from the European Consortium. ${ }^{33}$ Since genetic screening for MEN1 became available, more than 400 germline and somatic mutations have been identified in this gene. ${ }^{13,34}$ Most MEN1 mutations are inactivating, nonsense, or frameshift variants. Although splicing mutations represent only $5 \%$ of the overall mutations identified in the MENI gene, ${ }^{34}$ some of these disease-causing variants can be frequently found..$^{35}$ Furthermore, several missense MENI mutations have been identified, mostly occurring in evolutionary conserved sites, predicted to be related to retained relevant functions (Toledo RA et al., Clin Endocrinol (Oxf). 2007 Jun 6; [Epub ahead of print] PMID: 1755549, in press).
No hotspots have been found in the MEN1 gene; however, patients from different genetic backgrounds have shown recurrent mutations in GC-rich regions that are prone to slippage, suggesting mutational "warm-spot" areas in the MEN1 gene. ${ }^{33}$ To date, no relevant genotype-phenotype correlation has been reported. ${ }^{32}$ Also, interfamilial and intrafamilial phenotype variability has been demonstrated. ${ }^{32,33}$ Thus, relatives of individuals with MEN1 who harbor the same disease-causing mutation may present different clinical pictures. ${ }^{36}$

It has been reported that MEN1 mutation could not be found in up to $30 \%$ of familial MEN1 cases genetically tested. ${ }^{13}$ Technical limitations or the presence of mutations in the gene promoter region (which is not usually accessed in genetic screenings) may explain the finding of genetically negative MEN1 cases. ${ }^{13}$ Such a MEN1 mutation profile results in a laborious routine genetic investigation. At present, genetic screening for MENI abnormalities is mostly available in developed countries.

The MEN1 gene codifies for a 610 -amino acid protein named menin. ${ }^{37}$ Several tumor suppressor roles of menin have been disclosed so far, such as, a) cell cycle and cell growth control, b) transcription regulation, c) DNA repair, d) genome stability, e) apoptosis regulation, and f) endocrine cell proliferation. ${ }^{37,38}$ A MEN1 germline mutation predisposes the genome to a second mutational event concerning MEN1-associated glands, causing loss of heterozygosity $(\mathrm{LOH})$ of the $11 \mathrm{q} 13$ locus. The inactivation of menin is predicted to disrupt its tumor suppressor molecular pathways, thus leading to MEN1 tumorigenesis. ${ }^{37}$ These findings are consistent with the Knudson's 2-hit hypothesis for tumor suppressor genes. ${ }^{39}$

\section{State of art of MEN1 in Brazil}

To date, little information is known about the clinical and genetic profile of patients with MEN1 in Brazil. As occurs for other syndromes, such as sporadic HPT, for which specific screening programs are not performed in Brazil, ${ }^{40}$ it is likely that most patients with MEN1 present as symptomatic, late-diagnosed cases. To our knowledge, no public hospital other than Hospital das Clínicas in Brazil is routinely offering genetic testing for MEN1 gene mutations.

During the last 10 years, patients with MEN1 (and also MEN2) have been followed at the Disciplina de Endocrinologia of the Hospital das Clínicas, University of São Paulo, School of Medicine, at no charge through the Brazilian National System of Health (Sistema Único de Saúde, SUS). Our unit has developed expertise in diagnosis, management, and treatment of MEN1, and it has become one of the reference centers for this disease in Brazil. ${ }^{41-46}$ 
In this study, we report the results of clinical and genetic screenings of patients with MEN1. We also evaluated the impact of MEN1 genetic screening on the diagnosis and management of patients with MEN1, before and after its implementation. As far as we know, this is the first systematic genetic screening for MEN1 disease performed in South America.

\section{PATIENTS AND METHODS}

This study was approved by local ethics committee. Written informed consent was obtained from all patients undergoing genetic testing.

Briefly, the clinical screening of patients with MEN1 at our hospital started in 1997 and comprised the following 3 phases: phase 1 -systematic clinical identification of patients with MEN1 at this institution was performed; phase 2-MEN1 genealogies were expanded, and clinical screening was performed; and phase 3-the genetic testing for MEN1 was routinely incorporated into the clinical practice in our unit. The studied patients were followed for 10 years.

\section{Phase 1 - Identification of index cases of MEN1}

The criterion for the diagnosis of MEN1 was the presence of at least 2 MEN1-related tumors in the index cases. ${ }^{1}$ Hyperparathyroidism (HPT) was identified based on the presence of hypercalcemia associated with inappropriately elevated/borderline serum levels of parathyroid hormone (PTH). Prolactinoma was recognized by consistently high serum prolactin concentrations, menstrual irregularities, and/or hypogonadism associated with pituitary adenoma shown by MRI. Insulinoma was verified by clinical signs and symptoms of hypoglycemia associated with abnormal insulin/glucose ratios. Gastrinoma was documented by the presence of repetitive gastro-duodenal ulcers, gastric acid hypersecretion, hypergastrinemia, and endoscopic ultrasound findings. Somatotrophinoma was diagnosed through measurements of GH and IGF1; pituitary MRI was also performed. Cushing syndrome was diagnosed by clinical findings, ACTH/cortisol measurements, and image studies. Other rare involvements such as carcinoid tumors were also actively sought using standard clinical, biochemical, and image procedures.

\section{Phase 2 - Clinical screening of relatives at-risk for MEN1}

Familial MEN1 was defined when at least 1 MEN1-related tumor was found in a first-degree relative. At-risk family members were invited to come to the hospital for ex- ams. Clinical screening for MEN1-related neoplasias was performed, as recommended by the MEN Consensus. ${ }^{1,13}$ Annual biochemical exams and a tri-annual imaging investigation were performed. Those who presented biochemical or/and imaging abnormalities consistent with MEN1 and who had complaints related to MEN1 symptoms were diagnosed as affected. Relatives who had MEN1-related features at screening but no clinical symptoms were considered asymptomatic MEN1 cases. Relatives with no complaint and normal biochemical and imaging results were considered "not conclusive" and were invited to participate in the annual clinical screening.

\section{Phase 3 - MEN1 genetic analysis}

The optimization and standardization of genetic protocols for MENI mutation analysis were established in 2004. Laboratory procedures included, a) genomic DNA extraction from peripheral blood and oral swabs; b) amplification of the entire MEN1 coding region (exons 2-10) and also exon/intron boundaries by polymerase chain reaction (PCR); c) automated DNA sequencing, and d) MENI mutation analysis.

\section{Optimization and standardization of genetic protocols for $M E N 1$}

\section{DNA extraction}

After obtaining written informed consent, $10 \mathrm{~mL}$ of peripheral blood were collected (in 2 EDTA-containing tubes) from the 13 MEN1 probands. Genomic DNA was extracted according to a standard salting-out protocol or GFX Genomic Blood DNA Kit (Amersham Bioscience, Piscataway, NJ, USA). DNA from oral swab samples was obtained using the Chelex 100® (BioRad).

\section{MEN1 mutation analysis - Optimized protocol}

To perform the PCR amplification of the entire coding region (exons 2-10) and intron/exon boundaries of MEN1, we used specific primers as previously reported. ${ }^{32,47}$ To optimize PCR conditions, we used cycling temperatures and $\mathrm{MgCl}_{2}$ gradient assays in a MJ PTC-200 thermocycling apparatus (MJ Research). Best results were obtained using 200 ng of genomic DNA, $1 \mathrm{X}$ reaction buffer, $2.5 \mathrm{mM} \mathrm{MgCl}_{2}$, $0.5 \mathrm{mM}$ of each dNTP, 0.5 pmol of each primer and 1.25 U of Taq DNA polymerase (Invitrogen, São Paulo) in a total volume of $30 \mu \mathrm{L}$. Thermocycling conditions for the PCR were optimized as follows: $3 \mathrm{~min}$ at $94^{\circ} \mathrm{C}$, followed by 30 cycles of $1 \mathrm{~min}$ at $94^{\circ} \mathrm{C}, 45 \mathrm{~s}$ with a $65^{\circ} \mathrm{C}$-to- $60^{\circ} \mathrm{C}$ touchdown annealing temperature program (minus $1^{\circ} \mathrm{C}$ per cycle until $60^{\circ} \mathrm{C}$ was reached), and $1 \mathrm{~min}$ at $72^{\circ} \mathrm{C}$, followed 
by 10 min of final extension at $72^{\circ} \mathrm{C}$. The PCR products were confirmed by electrophoresis on a $1.5 \%$ agarose gel and purified using a Concert Rapid PCR Purification System kit (Life Technologies, Bethesda, MD).

Sequencing reactions were directly performed from purified PCR products using internal primers for both strands and Big Dye Terminator v3.1 (Applied Biosystems, Foster City, CA). Sequencing was carried on an automated sequencer (ABI Prism 310 DNA Analyzer, Applied Biosystems, Foster City), according to the manufacturer's recommendations. The homology of generated sequences was obtained using BLAST (http://www.ncbi.nlm.nih.gov/ BLAST). Two sequencing editor software programs (Gene StudioTM Professional Edition, Suwanee; and Mutation Surveyour, Softgenetics, PA, USA) were used to identify DNA abnormalities.

After the identification of the disease-causing MEN1 mutation in an index case, DNA samples from relatives who participated in the clinical screening (phase 2) were analyzed. First-degree relatives who did not participate in phase 2 were contacted and invited to come to the hospital and undergo the screening. To family members living far from São Paulo and claiming not to be able to travel, oral swabs were sent by mail. Furthermore, during the period of the project, several local visits were made by a physician (DML) and a social assistant from our group. They visited at-risk relatives of MEN1 patients who were interested in participating but to whom previous procedures were not applicable. This last approach was also used with families with extended genealogies living in a small geographic area. A total of 154 samples, 13 from patients who were MEN1 index cases and 141 from at-risk family members of patients with MEN1, were available for investigation.

Clinical follow-up and genetic counseling were offered to individuals who tested positive for MEN1 mutation. Furthermore, genetic testing was also offered to their descents. Individuals who did not inherit the mutant allele were excluded from MEN1 clinical screening protocol, and they were informed that their descents would not inherit the familial predisposition to MEN1-related tumors.

\section{Statistics}

ANOVA, Kruskall Wallis, and Mann-Whitney tests were used when applicable.

\section{RESULTS}

In phase 1 of the study, 13 MEN1 index cases were diagnosed. All index cases reported a familial history of MEN1. During phase 2 of the study, 28 patients with MEN1 were diagnosed. During phase 3, 11 MEN1 cases were discovered. These 11 patients decided to undergo clinical screening only after knowing that they were positive for a MEN1 mutation.

During the 10-year follow-up of these 13 families involving 52 individual cases of MEN1, the prevalence of MEN1related pathology was as follows: HPT, 94.2\% (49/52); pancreatic/duodenal endocrine tumors (PETs), 63.5\% (33/52); and pituitary tumors, $51.9 \%(27 / 52)$. Regarding the 49 cases of HPT, 38 (77.5\%) were symptomatic and 11 (22.5\%) were asymptomatic. Gastrinomas were the most common type of PET $(18 / 33 ; 54.5 \%)$, and $39.0 \%$ (7/18) of them were malignant, as documented by pathology/radiology findings. Insulinomas $(8 / 33 ; 24.2 \%)$ and exclusively nonsecretory tumors $(7 / 33 ; 21.2 \%)$ were also represented within PET cases. Furthermore, prolactinomas were the most frequent pituitary tumor $(18 / 27 ; 66.7 \%)$, whereas nonsecretory pituitary adenomas $(8 / 27 ; 29.6 \%)$ and somatotrophinoma $(1 / 27$; $3.7 \%$ ) were also present (Table 2).

Table 2 - Prevalence of major MEN1-related tumors in patients with MEN1: index cases (group I), clinically diagnosed cases (group II), and genetically diagnosed cases (group III).

\begin{tabular}{lccccc}
\hline & group & group & group & total of & literature* \\
& I & II & III & patients & $(\%)$ \\
& $(\mathrm{n}=13)$ & $(\mathrm{n}=28)$ & $(\mathrm{n}=11)$ & $(\mathrm{n}=52)$ & \\
& $(\%)$ & $(\%)$ & $(\%)$ & $(\%)$ & \\
\hline parathyroid (HPT) & 100 & 100 & 72.7 & 94.2 & $73-100$ \\
pancreas (PETs) & 76.9 & 67.9 & 27.3 & 63.5 & $30-80$ \\
gastrinoma & $(60)^{* *}$ & $(57.9)^{* *}$ & $(33)^{* *}$ & $(54.6)^{* *}$ & $30-75$ \\
insulinoma & $(50)^{* *}$ & $(15.8)^{* *}$ & $(0)^{* *}$ & $(24.2)^{* *}$ & $10-30$ \\
NS & $(0)^{* *}$ & $(26.3)^{* *}$ & $(67)^{* *}$ & $(21.2)^{* *}$ & \\
pituitary adenoma & 69.2 & 46.4 & 45.5 & 51.9 & $20-40$ \\
prolactinoma & $(77.8)^{* * *}$ & $(61.6)^{* * *}$ & $(60)^{* * *}$ & $(66.7)^{* * *}$ & 62 \\
NS adenoma & $(22.2)^{* * *}$ & $(38.4)^{* * *}$ & $(20)^{* * *}$ & $(29.6)^{* * *}$ & 15 \\
somatotrophinoma & $(0)^{* * *}$ & $(0)^{* * *}$ & $(20)^{* * *}$ & $(3.7)^{* * *}$ & 9 \\
ACTHoma & 0 & 0 & 0 & 0 & 4 \\
co-secreting & 0 & 0 & 0 & 0 & 10 \\
carcinoids & 7.7 & 10.7 & 0 & 7.7 & $>10$ \\
\hline
\end{tabular}

HPT, hyperparathyroidism; NS, exclusively nonsecreting

*References ${ }^{1,18,21,28}$

** \% relative to the cases of pancreatic endocrine tumors (PETs) in this particular group (one case had both gastrinoma and insulinoma).

$* * * \%$ relative to the cases of pituitary adenomas in this particular group

\section{MEN1 patient groups}

The mean ages at diagnosis (clinical or genetic) in groups I (39.5 $\pm 15.7 \mathrm{SD}$ years) and II $(42.4 \pm 15.0$ years $)$ did not significantly differ $(P>0.05)$. However, when both data were compared with group III $(27.0 \pm 14.0$ years $)$, significant differences were noticed ( $P=0.03 ; P=0.01$, respectively). The occurrence of 2 major secreting MEN1-related tumors in a 
single patient tended $(P=0.06)$ to be more prevalent in groups I and II, (7/13; $53.8 \%$ and $9 / 28 ; 32.2 \%$, respectively) than in group III $(1 / 11 ; 9.1 \%)$. Also, although 3 coexisting MEN1-related tumors in the same patient were more frequently seen in groups I and II $(6 / 13 ; 46.2 \%$ and $6 / 28$; $21.4 \%)$ than in group III $(1 / 11 ; 9.1 \%)$, no significant differences were noticed $(P=0.22)$. One isolated MEN1-related tumor occurred equally in groups II and III $(13 / 28 ; 46.4 \%$ and $8 / 11 ; 72.7 \%$, respectively), as shown in Table 3 .

\section{Malignancy and Mortality}

Malignancies in MEN1-related tumors were documented by the pathologic findings in 8 cases (data not shown) and/ or by the presence of either local or distant metastases in all of them. Malignant tumors were equally represented in groups I $(3 / 13,23.1 \%)$ and II $(5 / 28,17.9 \%)$. Metastases originated from gastrinomas $(6 / 8 ; 75 \%)$ or carcinoid tumors $(2 / 8 ; 25 \%)$. No patient in group III exhibited a malignant MEN1-related tumor (Table 3).

All 4 patients with carcinoid tumors were asymptomatic. The first patient had a gastric carcinoid that was identified and removed by endoscopy. The second had a bronchial carcinoid presenting local lymph node metastasis and underwent surgery. The third patient presented with an atypical, multiple metastatic pulmonary carcinoid, and the fourth had a pulmonary carcinoid tumor, but he refused any kind of treatment.

In the 10-year follow-up period (1997-2006), 4 of the 52 patients died of causes related to MEN1 disease as follows: 2 out of the 13 patients in group I (15.4\%) and 2 out of the 28 patients in group II $(7.1 \%)$. Three of them died due to metastatic gastrinoma, and 1 due to secondary complications of a nonsecretory pituitary macroadenoma. No death in group III has occurred (Table 3).

\section{MEN1-related tumor prevalence}

Primary hyperparathyroidism was diagnosed in all pa- tients in groups I and II (100\%) and in 8 patients (72.7\%) in group III. Asymptomatic HPT was present in patients from groups I (7.7\%) and II (21.4\%), but it prevailed in group III (50\%). Conversely, symptomatic HPT (nephrolithiasis) was seen mostly in patients of groups I and II $(87.8 \%)$ and was less represented in group III (50\%).

The prevalence of pancreatic/duodenal endocrine tumors (PETs) in groups I and II (76.9\% and 67.9\%, respectively) was higher than in group III (27.3\%). Within PET cases, gastrinoma was mostly present in groups I (60\%) and II $(57.9 \%)$ and less observed in group III (33\%). Most insulinomas were documented in groups I (50\%) and II $(15.8 \%)$ and were absent in group III. Conversely, exclusively nonsecretory PETs were only seen in groups III $(67 \%)$ and II $(26.3 \%)$.

Furthermore, in our patients with MEN1, pituitary adenomas were mostly diagnosed in group I (69.2\%) and were equally represented in groups II $(46.4 \%)$ and III (45.5\%). In all 3 groups, prolactinoma was highly prevalent (77.9\%, $61.6 \%$, and $60 \%$, respectively). Nonsecretory adenomas comprised $22.2 \%, 38.5 \%$, and $20 \%$, respectively.

Taking into account patients from all 3 groups, most MEN1 cases $(73.1 \%)$ were recognized after diagnosis of symptomatic HPT, as this condition was highly prevalent in all groups $(92.3 \%, 78.6 \%, 50 \%$, respectively). Moreover, symptomatic PET cases were significantly more frequent in groups I and II (50\%: 76.9\%) than in group III $(9 \% ; \mathrm{P}<0.05)$. Furthermore, symptomatic pituitary tumors were documented in all 3 groups $(61.5 \%, 28.6 \%$, and $36.4 \%$, respectively).

Furthermore, the annual clinical screening for MEN1 reported here allowed us to diagnose 29 asymptomatic MEN1-related tumors, as follows: 11 patients with HPT; 7 patients with non-secretory pancreatic endocrine tumors, 7 patients with non-secretory pituitary tumors, and 4 patients harboring malignant, asymptomatic carcinoid tumors.

Furthermore, after performing the genetic screening, 11

Table 3 - Clinical manifestations of MEN1 in patients with MEN1: index cases (group I), clinically diagnosed cases (group II), and genetically diagnosed cases (group III).

\begin{tabular}{lccc}
\hline & $\begin{array}{c}\text { probands(index cases) } \\
\text { (group I) }\end{array}$ & $\begin{array}{c}\text { patients diagnosed by familial } \\
\text { clinical screening(group II) }\end{array}$ & $\begin{array}{c}\text { patients diagnosed by MEN1 } \\
\text { genetic testing(group III) }\end{array}$ \\
\hline Mean age at diagnosis (years) & $39.5(18-74)$ & $42.4(18-61)$ & $27(14-56) *$ \\
0 MEN1-related tumor & - & - & $1(9.1 \%)$ \\
1 MEN1-related tumor & - & $13(46.4 \%)$ & $8(72.7 \%)$ \\
2 MEN1-related tumors & $7(53.8 \%)$ & $9(32.2 \%)$ & $1(9.1 \%) * *$ \\
3 MEN1-related tumors & $6(46.2 \%)$ & $6(21.4 \%)$ & $1(9.1 \%)$ \\
Tumor stage & advanced & early / advanced & $5(17.9 \%)$ \\
Malignancy & $3(23 \%)$ & $2(7.1 \%)$ & asymptomatic/ early \\
Mortality & $2(15.4 \%)$ & no metastasis & no death \\
\hline
\end{tabular}

$* P<0.05 ; * * \mathrm{p}=0.06$ 


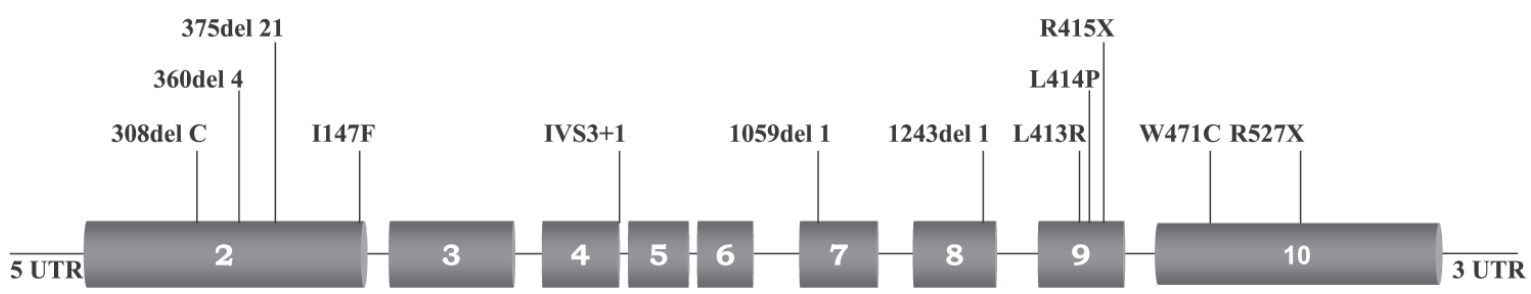

Figure 1 - The coding region (exons 2-10) of the MEN1 gene. MEN1 mutations identified in 13 MEN1 index cases are indicated. The mutation 360 del4 was localized in 2 unrelated patients with MEN1.

MEN1 mutation carriers were identified and included in the annual clinical follow-up.

\section{GENETIC RESULTS}

\section{Germline mutations in patients with MEN1 from HC- FMUSP}

The following disease-causing mutations where found through MEN1 mutation analysis: 308del1 (exon 2), proband 1; 375del21 (exon 2), proband 2; I147F (exon 2), proband 3, 360del4 (exon 2), probands 4 and 5; 1059del1 (exon 7), proband 6; 1243del1 (exon 8), proband 7; 1348T $>\mathrm{G}$ (exon 9), proband $8 ; 1351 \mathrm{~T}>\mathrm{C}$ (exon 9), proband $9 ; 1353 \mathrm{C}>\mathrm{T}$ (exon 9), proband 10;1523G $>\mathrm{T}$ (exon 10), proband 11; $1689 \mathrm{C}>\mathrm{T}$ (exon 10), proband 12; and IVS3+1 G>T (exon 2), proband 13 (Figure 1; Toledo RA et al., Clin Endocrinol (Oxf). 2007 Jun 6; [Epub ahead of print] PMID: 1755549, in press). All mutations were confirmed using a second DNA sample from an independently collected blood sample.

No mutational hot spot was found. Mutations of MENI were found at exons 2, 7, 8, 9, and 10; also, 1 splicing mutation was identified at intron 3. All identified MEN1 mutations were predicted to cause disruption of menin's transcriptional regulation or menin's protein interactions and thus lead to MEN1 tumorigenesis (Toledo RA, data not shown).

Additionally, we performed genetic testing of 141 relatives at-risk for MEN1. Thirty-nine relatives were identified as mutation carriers: 28 had previously undergone clinical exams (symptomatic cases), and 11 had not participated in the previous clinical screening. These 11 relatives after learning that they were positive for a MEN1 mutation agreed to adhere to the clinical screening. One hundred and one $(101 / 102,99 \%)$ relatives who were negative for a MEN1 mutation did not present MEN1-related complaints or symptoms, while 1 (1\%) developed sporadic primary HPT (MEN1 phenocopy).

\section{DISCUSSION}

Multiple endocrine neoplasia type 1 is an inherited dis- order with high penetrance, resulting in parathyroid, endocrine-pancreas/duodenum, and pituitary tumors. ${ }^{1,2} \mathrm{Sev}-$ eral other benign and malignant, endocrine and nonendocrine tumors have also been described for patients with MEN1. However, to date, very few data are available on patients with MEN1 from countries outside of North America, Europe, Japan, and Australia. In this report, we present the results of clinical and genetic MEN1 screenings performed in Brazil over a 10-year period. Also, we document important changes in the clinical presentation of patients with MEN1 after the implementation of the MEN1 genetic diagnosis.

Clinical manifestations in our MEN1 series are in accordance with those in the literature (Table 2). Thus, HPT was the most frequent (94.2\%) and usually the first manifestation of MEN1, as reported by Trump et al. ${ }^{3}$ The prevalence of PETs in our 52 MEN1 cases was as high as 63.5\%, and in groups I (76.9\%) and II (67.9\%) it was higher than in group III $(27.3 \%)$. The prevalence of pituitary adenomas in our MEN1 series (51.9\%) was slightly higher than previously reported (20\%-40\%, Table 2 ); however, our sample is still relatively limited for further conclusions. Finally, carcinoid tumors were equally presented in our patients and data from the literature (Table 2).

In this study, we were able to implement MEN1 mutation analysis in clinical practice. The genetic screening successfully identified MEN1 mutations in all 13 MEN1 index cases (Figure 1). Moreover, all 12 different MENI germline disease-causing mutations we identified are predicted to inactivate the tumor suppressor functions of menin and lead to MEN1 tumorigenesis. Although probands 4 and 5 had recurrent MEN1 mutations, no hot spot was found; mutations were spread throughout the coding and noncoding regions of the gene. This finding confirmed the need for searching the entire MEN1 coding region as well as its introns, which makes MEN1 genetic screening a laborious routine procedure. So far, genetic screenings for MEN1 have been performed in developed countries, whereas no such a program had so far been implemented in South America. Our data should be useful for improving management of the MEN1 syndrome in Brazil. 
The familial genetic screening included 141 family members at risk for MEN1 and has identified those who should undergo annual clinical surveillance of MEN1-related tumors and those who should be ruled out from clinical screening. Both positive and negative genetic results were worthwhile and highly informative in the management of individuals at risk for MEN1. The 39 at-risk relatives who inherited the affected MEN1 allele underwent complete surveillance for MEN1-related tumors. Furthermore, MEN1 genetic testing ruled out 102 family members who did not harbor a MEN1 mutation (and had no susceptibility for developing MEN1-associated neoplasias) from unnecessary following-ups, avoiding unnecessary, expensive exams and lifelong surveillance (Figure 2).

Genetic testing was also important for confirming MEN1 disease in previously diagnosed family members. Among such cases, we tested 1 relative presenting a primary HPT, who did not harbor a germline MEN1 mutation. According to MEN1 clinical criteria, this patient should have been diagnosed as a MEN1-affected case. However, he was indeed a sporadic HPT case. Such rare cases are called MEN1 phenocopies and do not need further surveillance for MEN1.$^{44,48,49}$ In the other hand, genetic testing for MEN1 mutations might disclose inherited cases within "sporadic" patients presenting either HPT at early ages (< $30 \mathrm{yr}$ ) or recurrent HPT. The latter patients should be genetically tested, and if a germline mutation is detected, a total parathyroidectomy followed by an autograph to the forearm or subtotal parathyroidectomy should be performed, instead of adenomectomy. ${ }^{1}$

It is largely accepted that the earlier the detection of neoplasias, the better is its management. Patients who are symptomatic for MEN1 usually require more aggressive and risky surgeries and a higher number of exams (Table 4). Also, the chance of cure could be reduced in late-diag-

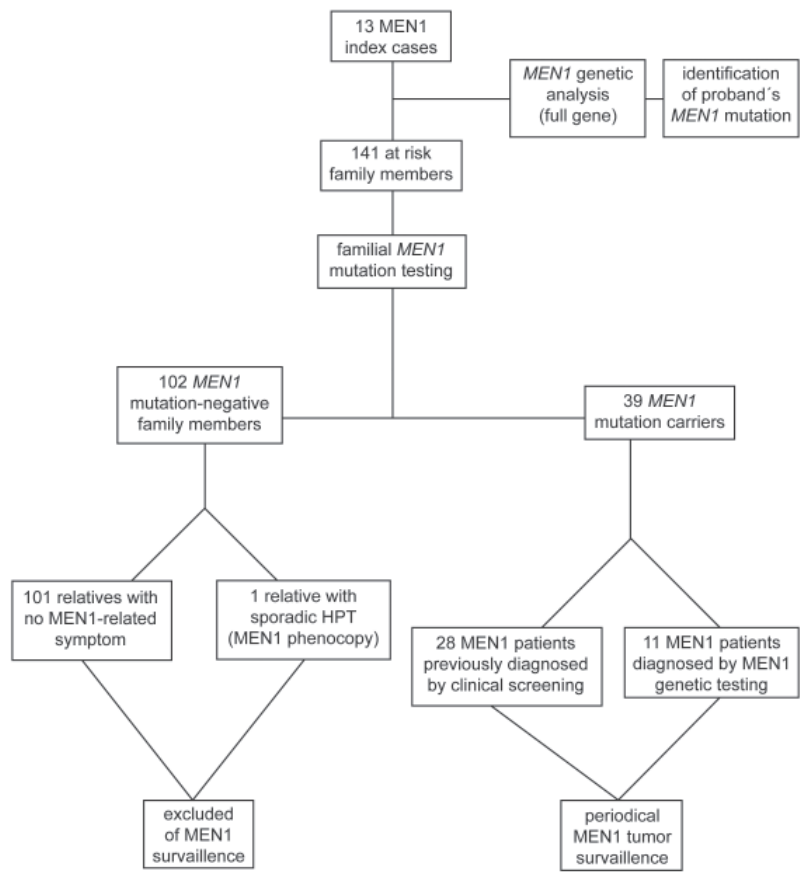

Figure 2 - MEN1 screening program.

nosed cases. ${ }^{16,17,25}$ Despite that, the identification of MEN1 mutations has been reported to have a limited influence in guiding early therapeutic surgery ${ }^{1,13}$; however, our data have shown a relevant impact of MENI genetic screening in the management of at-risk patients. Importantly, we noticed a shift towards milder clinical presentations in our 11 genetically diagnosed MEN1 patients. These patients (group III) presented different phenotypes from the clinically diagnosed patients (groups I-II) as follows, a) they were significantly (11-15 years) younger; b) they were usually asymptomatic; c) they mostly presented only 1 or no MEN1 tumor; d) they tended to present MEN1 tumors at their early stages; e) they had no MEN1-related malignancy; and f)

Table 4 - Usual major clinical manifestations of MEN1 at its early and late stages. Appropriate treatments for early- and late-diagnosed MEN1 patients are listed.

\begin{tabular}{|c|c|c|c|c|}
\hline \multirow[b]{2}{*}{ Major MEN1 manifestations } & \multicolumn{2}{|c|}{ Early recognition of MEN1 } & \multicolumn{2}{|c|}{ Late recognition of MEN1 } \\
\hline & Clinical features & Treatment & Clinical complications & Treatment \\
\hline Hyperparathyroidism & $\uparrow \mathrm{PTH} \quad \uparrow \mathrm{Ca}^{++}$ & total parathyroidectomy* & $\begin{array}{l}\text { renal complications osteoporosis, } \\
\text { renal calculi, renal insufficiency }\end{array}$ & $\begin{array}{l}\text { renal dialysis or } \\
\text { transplant }\end{array}$ \\
\hline Insulinoma & $\begin{array}{c}\text { †insulin } \quad \downarrow \text { glycemia, } \\
\text { hypoglycemic symptoms }\end{array}$ & surgery & $\begin{array}{l}\text { hypoglycemic shock, neuro- } \\
\text { psychiatric disorders, metastasis }(10 \%)\end{array}$ & surgery \\
\hline Gastrinoma & $\begin{array}{l}\text { gastrin, gastritis, ulcer, gastric } \\
\text { acid hypersecretion }\end{array}$ & drug therapy surgery & $\begin{array}{c}\text { esophageal stenosis, } \\
\text { gastroduodenal ulcers, metastasis } \\
(60 \%)\end{array}$ & $\begin{array}{l}\text { surgery chemotherapy } \\
\text { interpheron somatostatin } \\
\text { analogues }\end{array}$ \\
\hline Prolactinoma & microadenoma & drug therapy & $\begin{array}{l}\text { infertility, osteoporosis, hypogonadism, } \\
\text { macroadenoma,visual defects, }\end{array}$ & $\begin{array}{l}\text { drug therapy } \\
\text { radiotherapy surgery }\end{array}$ \\
\hline Thymic carcinoid & - & preventive thymectomy & metastasis & $\begin{array}{l}\text { surgery chemotherapy } \\
\text { radiotherapy }\end{array}$ \\
\hline
\end{tabular}

*with autograph to the forearm 
they all remained alive during the follow-up period (Tables 2-3). Our present findings corroborate a previous prospective study documenting that genetically diagnosed MEN1 patients have biochemical evidence 10 years preceding the signs and symptoms of the disease. ${ }^{50}$

Therefore, the implementation of a genetic screening program for MEN1 in a reference health center, such as our hospital, would be an important step for improving the management of this complex disease in Brazil. This program is a new effort among many others in the study of cancer and cancer prevention in Brazil. ${ }^{51-56}$ Also, such a program would save significant amounts of money spent on surveillance of patients that are negative for a MEN1 mutation.

In conclusion, we present the first clinical and genetic MEN1 screening trial performed in South America. Our study shows that MEN1 genetic testing greatly contributes to a more adequate clinical management of this complex syndrome and may benefit patient care.

\section{RESUMO}

Lourenco Jr. DM, Toledo RA, Coutinho FL, Margarido LC, Siqueira SAC, Cortina MA, Montenegro FL, Machado MC, Toledo SP. Impacto do rastreamento clínico e genético para Neoplasia Endócrina Múltipla tipo 1. CLINICS. 2007;62(4):465-76.

OBJETIVOS: Realizar rastreamentos clínico e gênico para Neoplasia Endócrina Múltipla tipo 1 (NEM1) e analisar seu impacto no seguimento clínico desses pacientes no Hospital das Clínicas, SP.

MÉTODOS: O diagnóstico clínico de NEM1 foi realizado de acordo com o Consenso sobre neoplasias endócrinas múltiplas. A análise genética para identificação de mutações foi realizada por sequenciamento automático de todas as regiões codificadoras e fronteiras exon/intron do gene MEN1. Os casos afetados foram sub-divididos em 3 
grupos e analisados separadamente: casos-índices (grupo I), familiares diagnosticados clinicamente (grupo II) e genicamente (grupo III).

RESULTADOS: Um total de 154 casos participou desse estudo, sendo 52 diagnosticados com NEM1: 13 do grupo I, 28 do grupo II e 11 do grupo III. A idade média ao diagnóstico no grupo III (27 anos) foi significativamente menor que a dos grupos I (39,5 anos; $p=0,03)$ e II $(42,4$ anos; $p=0,01)$. A maioria dos pacientes dos grupos I e II apresentou 2 ou 3 tumores, enquanto que $81,8 \%$ dos casos do grupo III apresentavam 1 ou nenhum tumor relacionado à NEM1. Além disto, 45,4\% dos casos do grupo III eram assintomáticos, não sendo observados nenhuma metástase ou óbito. Os demais 102 familiares sob-risco estudados não herdaram mutação MEN1 e foram excluídos do rastreamento clínico. Um caso de fenocópia NEM1 foi também localizado.

DISCUSSÃO: Nossos dados demonstraram importantes benefícios no seguimento dos pacientes NEM1, obtidos pela implementação dos rastreamentos clínico e gênico para essa doença.

UNITERMOS: Neoplasia endócrina múltipla. NEM1. Gene MEN1. Rastreamento. Diagnóstico gênico.

\section{References}

1. Brandi ML, Gagel RF, Angeli A, Bilezikian JP, Beck-Peccoz P, Bordi C, et al. Guidelines for diagnosis and therapy of MEN type 1 and type 2. J Clin Endocrinol Metab. 2001;86:5658-71.

2. Thakker RV. Multiple endocrine neoplasia type 1. Endocrinol Metab Clin North Am. 2000;29:541-67.

3. Trump D, Farren B, Wooding C, Pang JT, Besser GM, Buchanan KD, et al. Clinical studies of multiple endocrine neoplasia type 1 (MEN1). QJM. 1996;89:653-69.

4. Bilezikian JP, Potts JT Jr, Fuleihan Gel-H, Kleerekoper M, Neer R, Peacock M, et al. Summary statement from a workshop on asymptomatic primary hyperparathyroidism: a perspective for the 21 st century. J Clin Endocrinol Metab. 2002;87:5353-61.
5. Metz DC, Jensen RT, Bale AE, Skarulis MC, Eastman RC, Nieman L, et al. In: The Parathyroids: Raven Press, New Your, 1994, p. 591-647

6. Katai M, Sakurai A, Ikeo Y, Hashizume K. Primary hyperparathyroidism in patients with multiple endocrine neoplasia type 1: comparison with sporadic parathyroid adenomas. Horm Metab Res. 2001;33:499-503.

7. Mallette LE. Management of hyperparathyroidism in the multiple endocrine neoplasia syndromes and other familial endocrinopathies. Endocrinol Metab Clin North Am. 1994;23:19-36.

8. Burgess JR, David R, Greenaway TM, Parameswaran V, Shepherd JJ. Osteoporosis in multiple endocrine neoplasia type 1: severity, clinical significance, relationship to primary hyperparathyroidism, and response to parathyroidectomy. Arch Surg. 1999;134:1119-23. 
9. Thompson NW. The surgical management of hyperparathyroidism and endocrine disease of the pancreas in the multiple endocrine neoplasia type 1 patient. J Intern Med. 1995;238:269-80.

10. Carling T, Udelsman R. Parathyroid surgery in familial hyperparathyroid disorders. J Intern Med. 2005;257:27-37.

11. Glascock MJ, Carty SE. Multiple endocrine neoplasia type 1: fresh perspective on clinical features and penetrance. Surg Oncol. 2002;11:143-50.

12. Burgess JR, Greenaway TM, Shepherd JJ. Expression of the MEN-1 gene in a large kindred with multiple endocrine neoplasia type 1. J Intern Med. 1998;243:465-70

13. Marx SJ. Molecular genetics of multiple endocrine neoplasia types 1 and 2. Nat Rev Cancer. 2005;5:367-75

14. Grama D, Skogseid B, Wilander E, Eriksson B, Martensson H, Cedermark B, et al. Pancreatic tumors in multiple endocrine neoplasia type 1: clinical presentation and surgical treatment. World J Surg. 1992;16:611-8.

15. Norton JA, Fraker DL, Alexander HR, Venzon DJ, Doppman JL, Serrano $\mathrm{J}$, et al. Surgery to cure the Zollinger-Ellison syndrome. N Engl J Med. 1999:341:635-44.

16. Akerstrom G, Hessman O, Skogseid B. Timing and extent of surgery in symptomatic and asymptomatic neuroendocrine tumors of the pancreas in MEN 1. Langenbecks Arch Surg. 2002;386:558-69.

17. Akerstrom G, Hessman O, Hellman P, Skogseid B. Pancreatic tumours as part of the MEN-1 syndrome. Best Pract Res Clin Gastroenterol. 2005;19:819-30.

18. Verges B, Boureille F, Goudet P, Murat A, Beckers A, Sassolas G, et al Pituitary disease in MEN type 1 (MEN1): data from the France-Belgium MEN1 multicenter study. J Clin Endocrinol Metab. 2002;87:457-65.

19. Benson L, Ljunghall S, Akerstrom G, Oberg K. Hyperparathyroidism presenting as the first lesion in multiple endocrine neoplasia type 1 . Am J Med. 1987;82:731-7.

20. Samaan NA, Ouais S, Ordonez NG, Choksi UA, Sellin RV, Hickey RC. Multiple endocrine syndrome type I. Clinical, laboratory findings, and management in five families. Cancer. 1989;64:741-52.

21. Burgess JR, Shepherd JJ, Parameswaran V, Hoffman L, Greenaway TM Spectrum of pituitary disease in multiple endocrine neoplasia type 1 (MEN 1): clinical, biochemical, and radiological features of pituitary disease in a large MEN 1 kindred. J Clin Endocrinol Metab. 1996;81:2642-6.

22. Marx SJ, Vinik AI, Santen RJ, Floyd JC Jr, Mills JL, Green J 3rd. Multiple endocrine neoplasia type I: assessment of laboratory tests to screen for the gene in a large kindred. Medicine (Baltimore). 1986;65:226-41.

23. Daly AF, Jaffrain-Rea ML, Ciccarelli A, Valdes-Socin H, Rohmer V, Tamburrano G, et al. Clinical characterization of familial isolated pituitary adenomas. J Clin Endocrinol Metab. 2006;91:3316-23.

24. Asteria C, Anagni M, Persani L, Beck-Peccoz P. Loss of heterozygosity of the MEN1 gene in a large series of TSH-secreting pituitary adenomas. J Endocrinol Invest. 2001;24:796-801.

25. Teh BT, McArdle J, Chan SP, Menon J, Hartley L, Pullan P, et al Clinicopathologic studies of thymic carcinoids in multiple endocrine neoplasia type 1. Medicine (Baltimore). 1997;76:21-9.

26. Teh BT, Zedenius J, Kytola S, Skogseid B, Trotter J, Choplin H, et al Thymic carcinoids in multiple endocrine neoplasia type 1. Ann Surg. 1998:228:99-105
27. Gibril F, Chen YJ, Schrump DS, Vortmeyer A, Zhuang Z, Lubensky IA, et al. Prospective study of thymic carcinoids in patients with multiple endocrine neoplasia type 1. J Clin Endocrinol Metab. 2003;88:1066-81.

28. Kouvaraki MA, Shapiro SE, Cote GJ, Lee JE, Yao JC, Waguespack SG, et al. Management of pancreatic endocrine tumors in multiple endocrine neoplasia type 1. World J Surg. 2006;30:643-53.

29. Geerdink EA, Van der Luijt RB, Lips CJ. Do patients with multiple endocrine neoplasia syndrome type 1 benefit from periodical screening?

Eur J Endocrinol. 2003;149:577-82.

30. Skogseid B, Eriksson B, Lundqvist G, Lorelius LE, Rastad J, Wide L, et al. Multiple endocrine neoplasia type 1: a 10-year prospective screening study in four kindreds. J Clin Endocrinol Metab. 1991;73:281-7.

31. Skogseid B, Oberg K, Eriksson B, Juhlin C, Granberg D, Akerstrom G, et al. Surgery for asymptomatic pancreatic lesion in multiple endocrine neoplasia type I. World J Surg. 1996;20:872-6.

32. Chandrasekharappa SC, Guru SC, Manickam P, Olufemi SE, Collins FS, Emmert-Buck MR, et al. Positional cloning of the gene for multiple endocrine neoplasia-type 1. Science. 1997;276:404-7.

33. Lemmens I, Van de Ven WJ, Kas K, Zhang CX, Giraud S, Wautot V, et al Identification of the multiple endocrine neoplasia type 1 (MEN1) gene. The European Consortium on MEN1. Hum Mol Genet. 1997;6:1177-83.

34. Stenson PD, Ball EV, Mort M, Phillips AD, Shiel JA, Thomas NS, et al Human Gene Mutation Database (HGMD): 2003 update. Human Mutation. 2003;21:577-81.

35. Turner JJ, Leotlela PD, Pannett AA, Forbes SA, Bassett JH, Harding B, et al. Frequent occurrence of an intron 4 mutation in multiple endocrine neoplasia type 1. J Clin Endocrinol and Metab. 2002;87:2688-93.

36. Lourenco Jr DM, Coutinho FL, Toledo RA, Cavalcanti MG, Montenegro F, Machado MC, Toledo SPA. Variabilidade clínica na Neoplasia Endócrina Múltipla Tipo 1 (NEM-1): Estudo em 39 casos In: $27^{\circ}$ Congresso Brasileiro de Endocrinologia e Metabologia, 2006, Recife. Arq Bras Endocrinol Metab. 2006;(50):S639.

37. Agarwal SK, Kennedy PA, Scacheri PC, Novotny EA, Hickman AB, Cerrato A, et al. Menin molecular interactions: insights into normal functions and tumorigenesis. Horm Metab Res. 2005;37:369-74.

38. Balogh K, Racz K, Patocs A, Hunyady L.Menin and its interacting proteins: elucidation of menin function. Trends Endocrinol Metab. 2006;17:357-64.

39. Pannett AA, Thakker RV. Somatic mutations in MEN type 1 tumors, consistent with the Knudson "two-hit" hypothesis. J Clin Endocrinol Metab. 2001;86:4371-4

40. Ohe MN, Santos RO, Barros ER, Lage A, Kunii IS, Abrahao M, et al. Changes in clinical and laboratory findings at the time of diagnosis of primary hyperparathyroidism in a University Hospital in Sao Paulo from 1985 to 2002. Braz J Med Biol Res. 2005;38:1383-7.

41. Jorge BH, Agarwal SK, Lando VS, Salvatori R, Barbero RR, Abelin N, et al. Study of the multiple endocrine neoplasia type 1, growth hormonereleasing hormone receptor, Gs alpha, and Gi2 alpha genes in isolated familial acromegaly. J Clin Endocrinol Metab. 2001;86:542-4.

42. Lourenço Jr, DM, Toledo SPA. Neuroendocrinologia Clínica e Cirúrgica. In: Liberman \& Cukier. Neuroendocrinologia Clínica e Cirúrgica. São Paulo : Lemos Editora, 2002. p.577.

43. Lourenço-Jr DM, Toledo SPA, Toledo RA. Neoplasia Endócrina Múltipla tipo 1. In: Tratado de Clinica Médica.São Paulo: Roca, 2006. p.3535. 
44. Toledo RA, Lourenco Jr DM, Coutinho FL, Cavalcanti MG, Quedas E, Silva MER, et al. A Importância do Diagnóstico Molecular na Identificação de Fenocópias em Neoplasia Endócrina Múltipla Tipo 1. Arq Bras Endocrinol Metab 2006;(50):S619.

45. Lourenco Jr DM, Coutinho FL, Toledo RA, Quedas E, Cavalcanti MG, Montenegro, F, et al. Hiperparatieoidismo Assintomático (HPTa) na Neoplasia Endócrina Múltipla Tipo 1 (NEM-1). Arq Bras Endocrinol Metab. 2006;(50):S608.

46. Toledo RA, Lourenco Jr DM, Coutinho FL, Quedas E, Longuini VC, Moraes MB, et al. Estudo Gênico em pacientes com Neoplasia Endócrina Múltipla Tipo 1 (NEM-1). Arq Bras Endocrinol Metab. 2006;(50):S497.

47. Cote GJ, Lee JE, Evans DB, Huang E, Schultz PN, Dang GT, et al. Five novel mutations in the familial multiple endocrine neoplasia type 1 (MEN1) gene. Human Mutation. 1998;12:219.

48. Burgess JR, Nord B, David R, Greenaway TM, Parameswaran V, Larsson $\mathrm{C}$, et al. Phenotype and phenocopy: the relationship between genotype and clinical phenotype in a single large family with multiple endocrine neoplasia type 1 (MEN1).Clin Endocrinol (Oxf). 2000;53:205-11.

49. Hai N, Aoki N, Shimatsu A, Mori T, Kosugi S. Clinical features of multiple endocrine neoplasia type 1 (MEN1) phenocopy without germline MEN1 gene mutations: analysis of 20 Japanese sporadic cases with MEN1. Clin Endocrinol (Oxf). 2000;52:509-18.

50. Lairmore TC, Piersall LD, De Benedetti MK, Dilley WG, Mutch MG, Whelan AJ et al. Clinical genetic testing and early surgical intervention in patients with multiple endocrine neoplasia type 1 (MEN1). Ann Sug. 2004;239:637-45.
51. Toledo SP, dos Santos MA, Toledo Rde A, Lourenco Junior DM. Impact of RET proto-oncogene analysis on the clinical management of multiple endocrine neoplasia type 2. Clinics. 2006;61:59-70.

52. Santos MA, Nunes AB, Abelin N, Ezabella MC, Toledo Rde A, Toledo SP. Genetic screening of multiple endocrine neoplasia type 2: Experience of the USP Endocrine Genetics Unit. Arq Bras Endocrinol Metabol. 2006;50:7-16.

53. Stabenow E, Tavares MR, Ab'Saber AM, Parra-Cuentas ER, de Matos LL, Eher EM, et al. Angiogenesis as an indicator of metastatic potential in papillary thyroid carcinoma. Clinics. 2005;60:233-40.

54. Durazzo MD, de Araujo CE, Brandao Neto Jde S, Potenza Ade S, Costa $\mathrm{P}$, Takeda F, et al. Clinical and epidemiological features of oral cancer in a medical school teaching hospital from 1994 to 2002: increasing incidence in women, predominance of advanced local disease, and low incidence of neck metastases. Clinics. 2005;60:293-8.

55. Silva RV, Garicochea B, Cotti G, Maranho IC, Cutait R. Hereditary nonpolyposis colorectal cancer identification and surveillance of high-risk families. Clinics. 2005;60:251-6.

56. Waisberg J, de Matos LL, Dos Santos HV, Dos Santos AB, Reis GC, Capelozzi VL. Pancreatic carcinoid: a rare cause of diarrheagenic syndrome. Clinics. 2006;61:175-8. 